\title{
ANALYSIS OF \\ UNDERGRADUATE BIOLOGY LABORATORY MANUALS
}

\author{
Getachew Fetahi Gobaw ${ }^{1}$ \\ ${ }^{1}$ Ambo University, Team Leader, College of Natural and computational Science \& \\ Department of Biology, Instructor, Ethiopia, E-mail: getachewfetahi@yahoo.com
}

\begin{abstract}
The purpose of this study is to evaluate the undergraduate biology laboratory manuals of Ethiopian Universities. It focuses on assessing how they promote the basic and integrated science process skills that are involved in scientific inquiry with seven levels of Laboratory Task Analysis Instrument (LAI). A total of 22 undergraduate biology laboratory manuals were collected from three sample universities with different age. Manipulating materials, measuring and using numbers and pre - lab activities were common activities, and were found in every manual and in every university. However, students rarely asked to plan and design and to communicate and interpret the results. The results also show high percentage rate of basic science process skills (75.4\%) as compared to the integrated science process skills $(24.6 \%)$. Implications for universities and the Ministry of Education should develop standard harmonized biology laboratory manuals with all the necessary scientific skills that would promote the students' use of much integrated scientific skills.
\end{abstract}

Key words: Scientific Skills, Biology, Laboratory Manuals 


\section{Introduction}

Biology education plays important roles in human development in various areas such as medicine, agriculture, environmental protection and food security. It is important for students in their everyday life, in global competitiveness, resource utilization and environmental stewardship, in problem-solving skills, and understanding of the scientific methods (Kuddus, 2013). This can be realized when the quality of biology education is attained at better standards. Updating the standard and quality of biology education is essential to foster lifelong learning of students leading them to global excellence in education.

Biology practical activities are experiences in the learning -teaching process where students interact with materials to manipulate, observe and understand the natural world (Hofstein and Mamlok-Naaman, 2007). Students develop their understanding of scientific concepts, science inquiry skills, and perceptions of science in the laboratory; and laboratory activities include laboratory demonstrations, hands-on activities, and experimental investigations (Hofstein and Lunetta, 2004). Laboratory work is an active and interactive ways of teaching and learning method, which requires students to be involved in observing or manipulating real objects and materials, have a distinctive and central role for the development of students' understanding of scientific concepts, improving their cognitive skills, developing positive attitudes as well as stimulate students to greater efforts of achievement (Hunt, Koenders and Gynnild, 2012).

The laboratory work should successfully be used and effective in getting students to do what is intended to promote conceptual change (Abraham and Millar, 2008). The effectiveness of laboratory work is useful to consider the process of developing and evaluating a laboratory task. Psillos and Niedderer (2002) stated that the effectiveness of laboratory work is useful to consider the process of developing and evaluating a laboratory work task. Among the many variables to be considered are learning objectives and the laboratory (Lunetta, Hofstein, and Clough, 2007). To accomplish the objectives of science teaching, the laboratory manuals should provide the science process skills. The national science education standards (National Committee on Science Education Standards and Assessment, 1993) recommend that laboratory activities should be written in a manner so that students will use the following categories of skills: (a) formulate useable questions, (b) plan experiments, (c) conduct systematic observations, (d) interpret and analyse data, (e) draw conclusions, (f) communicate, and (g) coordinate and implement a full investigation. This study, therefore, focuses on the evaluation of the degree to which under graduate biology 
laboratory guides (manuals) promote the basic and integrated science process skills that are involved in scientific inquiry.

\section{The Role of Laboratory Manuals}

Literature showed that there are various factors that influence the acquisition of cognitive skills, such as science process skills (Domin, 1999; Pešaković, Flogie and Aberšek, 2014). Among the various factors, science curriculum is the one that affects students' practical work in the acquisition of science process skills. The laboratory manual is the part of science curriculum.

Several studies indicated that a process skill-based science curriculum, can contribute positively towards the expected science learning outcomes. The laboratory manual reduces the amount of time necessary to complete a laboratory activity by providing an instructional pathway that does not require the utilization of higher -order thinking skills and has become an instrument that maximizes laboratory efficiency at the expense of fostering higher-order cognition (Domin,1999). The laboratory manual plays a central role in shaping the students' behaviours and learning, and in defining goals and procedures (Hofstein and Lunetta, 2004). Laboratory manuals are important components of science instruction and should be evaluated for their use of inquiry. Sundberg and Moncada (1994) stated that manuals for implementing an investigative laboratory program in a classroom should contain awareness and purpose of investigation, initial series of activities that prepare students to investigate, formulate problems and investigatory procedures, to repeat and/or modify experiments and prepare written and/or oral reports. Similarly, Germann, Haskins and Auls (1996) stated that the laboratory manuals should provide students with step-by-step detailed instructions and ask them to manipulate materials, make observations and measurements, record results, make qualitative and quantitative relationships, draw conclusion, make inferences and generalizations, and communicate and interpret the results. Manuals should also include much inquiry and they often engage students in the planning and designing of the activities, and they should also encourage students to apply the skills or techniques they have learned to new situations (Tweedy and Hoese, 2005). However, the task of creating a meaningful and relevant curriculum-based on the necessary skills of the 21 st century is not an easy one (Gauchet, 2011).

A few analyses of science lab manuals using the Laboratory Structure and Task Analysis Inventory (LAI) have been done. For example, Tamir and Lunetta (1978) have analyzed secondary high schools science laboratory manuals by 16-item Laboratory Structure and Task Analysis Inventory (LAI). They found that lab manuals foster students' 
manipulative skills, qualitative and quantitative relationships, and inferences to drawing conclusions, and communicating results in scientific investigations. The manuals, however, were lacking in inquiry skills such as designing experiments, formulating hypotheses, applying experimental techniques to new investigations, and reflecting on possible sources of errors.

Germann, Haskins and Auls (1996) studied seven high school biology laboratory manuals using a modified version of Tamir and Lunetta(1978) lab manual inventory. Germann et al. (1996) concluded that most manuals did not provide opportunities for students to pose a question to be investigated, formulate a hypothesis to be tested, or predict experimental results; to design observations, measurements, and experimental procedures; to work according to their own design; or to formulate new questions or apply an experimental technique based on the investigation they performed.

Basey, Mendelow and Ramos (2000) investigated laboratory manuals at six randomly chosen community colleges in Colorado on how science inquiry and technology were incorporated into lab exercises. They showed that most of the exercises investigated a particular problem or hypothesis instead of allowing students to formulate a problem or to solve hypothesis.

Tweedy and Hoes (2005) did the most recent content analysis of 10 community college laboratory manuals analysis using a modification of Basey et al. (2000) inventories. They showed that the laboratory manuals failed in promoting higher-order cognition. They concluded that most manuals did not include much inquiry and often failed to engage students in the planning and designing of the activity, and they did not encourage students to apply what they learned in a broader context. Science educators recommended that major revisions of the science curriculum at various levels that courses emphasize science as a way of knowing and that they permit students to learn and experience scientific processes (Tweedy and Hoese, 2005). Many of the past laboratory task inventories have done mainly on commercial college laboratory manuals, secondary high schools biology laboratory and other science disciplines manuals. The science laboratory tasks are practical activities important in the construction of scientific knowledge, especially biological knowledge, at university levels in Ethiopia. The tasks should be included in the laboratory manuals. However, no analysis has been done so far on the biology laboratory manuals to determine the presence of such activities. 


\section{Inquiry and Science Process Skills}

Inquiry can be an effective teaching approach to support students' learning for long-term retention. Promoting inquiry in the laboratory empowers the students to take these trained skills and conduct further investigations. Hence, laboratory activities provide excellent opportunities to incorporate inquiry in to the curriculum (Tweedy and Hoese, 2005). Inquiry-based biology laboratory instruction improves scientific skills and critical thinking.

Özgelen (2012) defined science process skills as they are the thinking skills scientists use to construct knowledge in order to solve problems and formulate results. According to Jack (2013), science process skills are cognitive and psychomotor skills employed in problem solving process and in the acquisition of science process skills which are the basis for scientific inquiry, development of intellectual skills and attitudes that are needed to learn concepts. These skills can be acquired and developed through science practical activities and retained when cognitive knowledge has been forgotten. Tarrant (2005) stated that students who are scientifically literate should possess skills such as the ability to think critically, use scientific reasoning, and interpret various types of data, use facts and logic to solve problems, formulate arguments, and understand the world in which they live. These skills help students to be global citizens and practice environmental stewardships. The biology practical skills are science process skills that are taught as part of the biology curriculum and these skills can be acquired and developed through activities involved in the biology practical sessions (Ongowo and Indoshi, 2013).

The American Association for the Advancement of Science (AAAS, 1993) has categorized science process skills into Basic Science Process Skills, and Integrated Science Process Skills. Basic science process skills consist of observing, using space or time relationships, inferring, measuring, communicating, classifying, and predicting, whereas integrated science process skills include controlling variables, defining operationally, formulating hypotheses, interpreting data, experimenting, formulating models, and presenting information. According to Sheeba (2013), the science process skills enable the students to apply scientific concepts, procedures and attitudes to their wider life. Therefore, these skills affect the personal, social, and global lives of individuals.

There are different approaches of classifications of laboratory tasks. Banchi and Bell (2008) have classified the science education of inquiry-based learning in to four levels, namely confirmation inquiry, structured inquiry, guided inquiry and open inquiry. The levels focus on how much information (e.g., guiding question, procedure, and expected results) is provided to students, and how much guidance is provided by the teacher. At the first level 
(confirmation inquiry) students are provided with the question and procedure (method), and the results are known in advance. In the second level (structured inquiry) the question and procedure are still provided by the teacher; and students are expected to generate an explanation supported by the evidence they have collected. In the third level (guided inquiry) the teacher provides students with only the research question, and then the students design the procedure (method) to test their question and the resulting explanations. In the fourth and highest level of inquiry (open inquiry) students generate their own questions, plan their investigation, collect and organize their data, and communicate their results. This level requires the most scientific reasoning and greatest cognitive demand from students.

Developing countries like Ethiopia need skilled man power to expand educational opportunities by creating access and encouraging innovation and creativity. There is a need for the provision of affordable education services along with up to date learning resources with compromising quality and standard.

According to the country's Harmonized Curriculum for BSc Degree program In biology, 1994), the objectives of the BSc Degree Program in biology are to enable students acquire practical and technical skills required for utilizing biological tools and to train and provide students who can design and apply the principles of biology to identify and solve societal problems related to environment, agriculture, health, industry and teaching. To meet these objectives, the Ethiopian Government is working to re-align its higher education system so that it can contribute more directly to its national strategy for economic growth and poverty reduction. Hence, undergraduate biology students need to develop biology skills that will equip them for their future life; enable them to solve day- to- day problems and think critically.

In Ethiopian universities practical activities are part of biology education. There is a need to produce graduates who have the appropriate practical skills, attitudes and experiences to create work for their own and the communities as well, fit to be employed in different biological disciplines. The laboratories should be more efficient in accomplishing the objectives of learning- teaching science than other models of instruction because laboratory work is both time consuming and expensive as compared with other models. Thus, the gap between the theoretical notions of biology laboratory work and the actual practices of laboratory work in universities requires some examination so that biology laboratory activities could be better designed and implemented, and is able to fulfil their promises. 
By increasing the understanding that effective biology education is a critical for advancing scientific and social development, biology curriculum reforms were made in higher educations. The science laboratory tasks are practical activities important in the construction of scientific knowledge, especially biology knowledge at university levels in Ethiopia. However, no analysis has been done so far on the biology laboratory manuals to determine the presence of such activities. Therefore, there is need to investigate and fill in the existing gap regarding the extent of science process skills inherent in Ethiopian universities for the undergraduate biology laboratory manuals.

The purpose of this study was to evaluate the undergraduate biology laboratory manuals for the extent of science process skill acquisition in some Ethiopian universities using seven levels of Laboratory Task Analysis Instrument (LAI) and then advising higher education authorities on how to improve the teaching and learning of practical biology in the country.

The study here in should answer the following three questions.

1. What is the level of scientific skills in undergraduate biology laboratory activities of Ethiopian universities?

2. What is the prominent science process skills included in the undergraduate biology laboratory of Ethiopian universities?

\section{Methodology}

This study addressed the evaluation of undergraduate biology laboratory manuals in Ethiopian universities in order to recommend to the higher institutions so as to improve the learningteaching process of biology laboratory practical activities.

From all the government universities in Ethiopia, three universities were purposefully selected as case study. There are two reasons why these universities are selected. Firstly, the universities have different length of work experiences and recourses. University " $A$ " or "Aged" has over 20 years of teaching experience, University "B" or " Middle-aged" has about 10 years of teaching experiences and University "C" or "New University" has 6 years of experience. Secondly, the locations of the universities to the researcher are appropriate to manage the data collection process properly and are found in the same administrative region.

Laboratory manuals are handbook, or worksheet (Hofstein and Lunetta, 2003) that should provide step-by step detailed instructions in each laboratory exercise (Germann , et al., 1996). Laboratory exercise is defined as an individual experiment or observation set up in a 
laboratory manual to investigate a particular problem or hypothesis (Peters, 2006). The available laboratory manuals used in each university were collected. All the laboratory manuals were not published but prepared by the instructors in the universities. Each activity in each course was evaluated with seven categories of Laboratory Task Analysis Instrument (LAI) modified version of Tweedy and Hoese (2005) laboratory task analysis unventory . The instrument was first developed by Tamir and Lunetta (1978) and Germann et al. (1996) with certain modification. There are two main reasons for the need to modify the laboratory task analysis used by Tweedy and Hoese (2005). Firstly, the measuring and using numbers and manipulative materials are incorporated here in this study because these skills are important science process skills that students should acquire in biology laboratory. Secondly, scientific communication is included in this study because it is an important science process skill.

The laboratory exercise requirement of the undergraduate biology curriculum for BSc Degree Program in Biology (2009) syllabus was examined to gain information on the number and type of laboratory exercises recommended. Then, after the analysis of the curriculum syllabus, the analysis of the available biology laboratory manuals for each course in each university was conducted to get information in the number of laboratory exercises recommended to laboratory instructors. The basic and integrated science process skills were categorized in the seven categories. The analysis of the manuals were done by evaluating whether the student is asked to 1) prepare before lab ,2) plan and design , 3) measure and use numbers , 4) manipulate materials, 5) record results, make qualitative and quantitative relationships,6) draw conclusions, and 7) communicate and interpret the results.

A single laboratory exercise from each laboratory manual was assessed by the researcher and another evaluator. The inter-rater reliability was $83.5 \%$. The collected data was summarized at the university level.

\section{Results}

The Harmonized Curriculum for BSc Degree Program in Biology (Addis Ababa, Ethiopia, 2009) recommends that 146 laboratory practical sessions in 14 biology courses throughout the entire program. A total of 22 biology laboratory manuals in the three universities were evaluated with seven categories of Laboratory Task Analysis modified from Tweedy and Hoese (2005) laboratory task analysis inventory .Of the 14 biology courses recommended in the curriculum to have laboratory activities, the number of courses having laboratory manuals are $2(14.3 \%), 7$ (50\%) and $13(92.86 \%)$ in the new, medium and old universities respectively. The number of laboratory sessions recommended by the manuals are 90(61.4\%), 52 (35.6\%) 
and $14(9.6 \%)$ in the new, medium and old universities respectively. A total of 838 activities were given in the manuals of the three universities.

Of these, 414(49.64\%), 298(35.73\%) and 122(14.63\%) activities are in old, middleaged and new universities respectively. However, students rarely asked to plan and design and to communicate and interpret the results. The results of this study also show high percentage rate of basic science process skills $(75.4 \%)$ as compared to the integrated science process skills $(24.6 \%)$.

The seven categories of Laboratory Task Analysis Instrument used in the study in their decreasing order were manipulating materials (26.02\%), measuring and using numbers (24.94\%), pre-lab activities, such as reading, observation and questioning (20.14\%), recording results, making qualitative and quantitative relationships( $12.35 \%)$, drawing conclusion, making inferences, and making generalization( 11.03\%), communicating and interpreting results $(4.32 \%)$ and planning and designing(1.2\%) manipulating materials, measuring and using numbers and pre lab activities were the common activities, and were found in every manual and in all the three universities.

As shown in Table 1 below, reading was the most common pre-lab activity (17.63\%) and was found in every manual and every university. Answering initial questions and preliminary observations were present only in two manuals of the old and new universities, each in a single activity occurred in $9 \%$ and $2 \%$ of the activities.

Table 1. The biology laboratory exercise analysis inventory of manuals in different universities- I. Pre lab activities

\begin{tabular}{llllll}
\hline Description of Evaluation criteria & $\begin{array}{l}\text { University A } \\
\text { ( Old) }\end{array}$ & $\begin{array}{l}\text { University-B } \\
\text { (Middle- } \\
\text { aged) }\end{array}$ & $\begin{array}{l}\text { University A } \\
\text { ( New) }\end{array}$ & $\begin{array}{c}\text { Total } \\
\text { activities }\end{array}$ & $\%$ \\
\hline I. Pre-Lab Activities & & & & & \\
a. Reading & 81 & 52 & 14 & 147 & 17.63 \\
b. Questions & 9 & - & 2 & 11 & 1.32 \\
c. Observations & 9 & - & 1 & 10 & 1.20 \\
Total & $\mathbf{9 9}$ & $\mathbf{5 2}$ & $\mathbf{1 7}$ & $\mathbf{1 6 8}$ & $\mathbf{2 0 . 1 4}$ \\
\hline
\end{tabular}

As shown in Table 2, reading was the most common pre-lab activity (1.2\%) and was found only in the middle-aged university. Three manuals required students to plan and design their experiments in the middle- aged university. In one activity, students were asked to identify independent and dependent variables, in three activities to use experimental control, in one activity to design observation, and in a single activity to predict experimental results. None of the manuals asked students to formulate questions and hypothesis, to identify independent variables, design their experiment and design data tables. 
Table 2. The biology laboratory exercise analysis inventory of manuals in different universities- II. Planning and designing

\begin{tabular}{|c|c|c|c|c|c|}
\hline Description of Evaluation criteria & $\begin{array}{l}\text { University A } \\
\text { ( Old) }\end{array}$ & $\begin{array}{l}\text { University-B } \\
\text { ( Middle- } \\
\text { aged) }\end{array}$ & $\begin{array}{l}\text { University A } \\
\text { ( New) }\end{array}$ & $\begin{array}{c}\text { Total } \\
\text { activities }\end{array}$ & $\%$ \\
\hline \multicolumn{6}{|l|}{ II. Planning and Designing } \\
\hline a. Formulates question/problem & - & - & - & & 0.00 \\
\hline b. Formulates hypothesis & - & - & - & & 0.00 \\
\hline c. Identifies independent variable & - & - & & & 0.00 \\
\hline d. Identifies dependent variable & - & 1 & - & 1 & 0.12 \\
\hline e. Identifies constant variables & - & 1 & - & 1 & 0.12 \\
\hline f. Experimental control & - & 6 & - & 6 & 0.72 \\
\hline g. Designs observations & - & 1 & - & 1 & 0.12 \\
\hline h. Designs experiments & - & - & - & 0 & 0.00 \\
\hline i. Designs data table & - & - & - & 0 & 0.00 \\
\hline j. Predicts experimental results. & - & 1 & - & 1 & 0.12 \\
\hline Total & 0 & 10 & 0 & 10 & 1.20 \\
\hline
\end{tabular}

Table 3 below shows that students are most often asked to identify the measurement required, specify the instrument to be used, choosing and using standard units, add up the total measurements, recording units correctly and comparing time, distance, area and volume with relevant units in most manuals of all the three universities.

Table 3. The biology laboratory exercise analysis inventory of manuals in different universities- III. Measuring and Using Numbers

\begin{tabular}{|c|c|c|c|c|c|}
\hline Description of Evaluation criteria & $\begin{array}{l}\text { University A } \\
\text { ( Old) }\end{array}$ & $\begin{array}{l}\text { University-B } \\
\text { ( Middle- } \\
\text { aged) }\end{array}$ & $\begin{array}{l}\text { University A } \\
\text { ( New) }\end{array}$ & $\begin{array}{c}\text { Total } \\
\text { activities }\end{array}$ & $\%$ \\
\hline \multicolumn{6}{|l|}{ III. Measuring and Using Numbers } \\
\hline $\begin{array}{l}\text { a. Identify the measurement } \\
\text { required. }\end{array}$ & 24 & 17 & 7 & 48 & 5.76 \\
\hline b. Specify the instrument to be used. & 21 & 14 & 7 & 42 & 5.04 \\
\hline c. Choosing and using standard unit & 17 & 13 & 7 & 37 & 4.44 \\
\hline d. Add up the total measurement & 15 & 8 & 4 & 27 & 3.24 \\
\hline e. Recording unit correctly & 17 & 12 & 3 & 32 & 3.84 \\
\hline $\begin{array}{l}\text { f. Comparing time, distance, area } \\
\text { and volume with relevant units }\end{array}$ & 7 & 11 & 4 & 22 & 2.64 \\
\hline Total & 101 & 75 & 32 & 208 & 24.94 \\
\hline
\end{tabular}

As shown in Table 4, using and handling science apparatus (9.83\%) and handling specimen correctly and carefully (10.07\%) were the most frequently asked activities among the skills of manipulating materials. Maintaining science apparatus correctly and safely and sketching specimen and science apparatus were rarely asked activities in the manuals.

Students were most often asked to perform qualitative relationship than quantitative relationship and were rarely asked to summarize their data in tables and graphs (Table 5). They were asked to determine the accuracy of the observed experimental data only in a single activity. 
Table 4. The biology laboratory exercise analysis inventory of manuals in different universities- IV. Manipulate Materials

\begin{tabular}{|c|c|c|c|c|c|}
\hline Description of Evaluation criteria & $\begin{array}{l}\text { University A } \\
\text { ( Old) }\end{array}$ & $\begin{array}{l}\text { University-B } \\
\text { ( Middle- } \\
\text { aged) }\end{array}$ & $\begin{array}{l}\text { University A } \\
\text { ( New) }\end{array}$ & $\begin{array}{c}\text { Total } \\
\text { activities }\end{array}$ & $\%$ \\
\hline \multicolumn{6}{|l|}{ IV. Manipulate Materials } \\
\hline $\begin{array}{l}\text { a. Using and handling science } \\
\text { apparatus }\end{array}$ & 28 & 36 & 18 & 82 & 9.83 \\
\hline $\begin{array}{l}\text { b. Maintaining science apparatus } \\
\text { correctly and safely }\end{array}$ & 11 & - & - & 11 & 1.32 \\
\hline $\begin{array}{l}\text { c. Cleaning science apparatus } \\
\text { correctly }\end{array}$ & 7 & 8 & 2 & 17 & 2.04 \\
\hline $\begin{array}{l}\text { d. Handling specimen correctly and } \\
\text { carefully }\end{array}$ & 47 & 21 & 16 & 84 & 10.07 \\
\hline $\begin{array}{l}\text { e. Sketch specimen and science } \\
\text { apparatus }\end{array}$ & 20 & 3 & - & 23 & 2.76 \\
\hline Total & 113 & 68 & 36 & 217 & 26.02 \\
\hline
\end{tabular}

Table 5. The biology laboratory exercise analysis inventory of manuals in different universities- V. Record Results, Make Qualitative and Quantitative Relationships

\begin{tabular}{|c|c|c|c|c|c|}
\hline Description of Evaluation criteria & $\begin{array}{l}\text { University A } \\
\text { ( Old) }\end{array}$ & $\begin{array}{l}\text { University-B } \\
\text { ( Middle- } \\
\text { aged) }\end{array}$ & $\begin{array}{l}\text { University A } \\
\text { ( New) }\end{array}$ & $\begin{array}{c}\text { Total } \\
\text { activities }\end{array}$ & $\%$ \\
\hline \multicolumn{6}{|l|}{$\begin{array}{l}\text { V. Record Results, Make Qualitative } \\
\text { and Quantitative Relationships }\end{array}$} \\
\hline $\begin{array}{l}\text { a. Recording information from } \\
\text { investigations }\end{array}$ & 5 & 6 & 2 & 13 & 1.56 \\
\hline b. Results summarized in a table & 4 & 6 & 1 & 11 & 1.32 \\
\hline c. Graphs data & 1 & 2 & 8 & 11 & 1.32 \\
\hline $\begin{array}{l}\text { d. Determines qualitative } \\
\text { relationships }\end{array}$ & 22 & 25 & 6 & 53 & 6.35 \\
\hline $\begin{array}{l}\text { e. Determines quantitative } \\
\text { relationships }\end{array}$ & 6 & 5 & 3 & 14 & 1.68 \\
\hline $\begin{array}{l}\text { f. Determines accuracy of } \\
\text { experimental data }\end{array}$ & - & 1 & - & 1 & 0.12 \\
\hline Total & 38 & 45 & 20 & 103 & 12.35 \\
\hline
\end{tabular}

Table 6. The biology laboratory exercise analysis inventory of manuals in different universities-VI. Draw Conclusions, Make Inferences and Generalizations

\begin{tabular}{llllll}
\hline \multicolumn{1}{c}{ Description of Evaluation criteria } & $\begin{array}{l}\text { University A } \\
\text { ( Old) }\end{array}$ & $\begin{array}{l}\text { University-B } \\
\text { (Middle- } \\
\text { aged) }\end{array}$ & $\begin{array}{l}\text { University A } \\
\text { ( New) }\end{array}$ & $\begin{array}{l}\text { Total } \\
\text { activities }\end{array}$ & $\%$ \\
\hline $\begin{array}{l}\text { VI. Draw Conclusions, Make } \\
\text { Inferences and Generalizations }\end{array}$ & & & & & \\
a. Draws conclusions & 34 & 22 & 10 & 66 & 7.91 \\
b. Provides evidence & 2 & 3 & 1 & 6 & 0.72 \\
c. Discusses limitations/assumptions & 5 & 4 & 1 & 10 & 1.20 \\
d. Formulates generalization/model & 6 & 1 & - & 7 & 0.84 \\
e. Makes inferences & 1 & 1 & 1 & 3 & 0.36 \\
Total & $\mathbf{4 8}$ & $\mathbf{3 1}$ & $\mathbf{1 3}$ & $\mathbf{9 2}$ & $\mathbf{1 1 . 0 3}$ \\
\hline
\end{tabular}


Students were required to draw conclusions based on the results, but they were rarely required to support their conclusions with evidence, to discuss the limitations or assumptions, to formulate model and to make inferences (Table 6).

Students were rarely asked to express their ideas or meanings, to record information from investigations, to draw and make notes, to write experiment reports to enable others to repeat the experiment and to use references. None of the manuals asked students to use and explain the meaning of symbols.

Table 7. The biology laboratory exercise analysis inventory of manuals in different universities-VII. Communicate and Interpret The Results

\begin{tabular}{|c|c|c|c|c|c|}
\hline Description of Evaluation criteria & $\begin{array}{l}\text { University A } \\
\text { ( Old) }\end{array}$ & $\begin{array}{l}\text { University-B } \\
\text { ( Middle- } \\
\text { aged) }\end{array}$ & $\begin{array}{l}\text { University A } \\
\text { ( New) }\end{array}$ & $\begin{array}{c}\text { Total } \\
\text { activities }\end{array}$ & $\%$ \\
\hline \multicolumn{6}{|l|}{$\begin{array}{l}\text { VII. Communicate and Interpret The } \\
\text { Results }\end{array}$} \\
\hline a. Express ideas or meanings & - & 13 & 1 & 14 & 1.68 \\
\hline b. Drawing and making notes & 13 & 1 & 1 & 15 & 1.80 \\
\hline $\begin{array}{l}\text { c.Writing experiment report to } \\
\text { enable others to repeat the } \\
\text { experiment }\end{array}$ & 1 & 1 & - & 2 & 0.24 \\
\hline d. Using references & 1 & 2 & 2 & 5 & 0.60 \\
\hline Total & 15 & 17 & 4 & 36 & 4.32 \\
\hline
\end{tabular}

Table 8. The biology laboratory exercise analysis inventory of manuals in different universities

\begin{tabular}{cllll}
\hline Description of Evaluation criteria & $\begin{array}{l}\text { University A } \\
\text { ( Old) }\end{array}$ & $\begin{array}{l}\text { University-B } \\
\text { ( Middle- } \\
\text { aged) }\end{array}$ & $\begin{array}{l}\text { University A } \\
\text { ( New) }\end{array}$ & $\begin{array}{c}\text { Total } \\
\text { activities }\end{array}$ \\
\hline $\begin{array}{c}\text { Number of courses with manuals } \\
\text { Total Number of laboratory activities }\end{array}$ & 13 & 7 & 2 & 22 \\
$\begin{array}{c}\text { recommended in the manuals } \\
\text { Grand Total }\end{array}$ & 90 & 52 & 14 & 156 \\
$\%$ & 414 & 298 & 122 & 834 \\
\hline
\end{tabular}

\section{Discussion}

Manipulating materials, measuring and using numbers and pre lab activities were common activities, and were found in every manual and in every university. However, students were rarely asked to plan, design and to communicate and interpret the results. The result of this study found to be in agreement with other studies carried out elsewhere (Saha, 2001; Haskins, 2000). Saha (2001) showed that students demonstrate more skills in performing than planning and reasoning, and the students' performances at the item level were very poor for some items. 
Findings of the seven categories of Laboratory Task Analysis Instrument used in this study has revealed that very few (3 out of 22) manuals asked students to plan and design their experiments. The integrated science process skills are very few (24.6\%) as compared to the basic science process skills $(75.4 \%)$. The result of this study found to be in agreement with other studies (Germann et al., 1996; Basey et al. 2000; Tweedy and Hoese, 2005; Akinbobola and Afolabi, 2010). However, the percent of the integrated science process skills in this study is $24.6 \%$ while Akinbobola and Afolabi's is $37.2 \%$, which is very less.

None of the manuals asked students to formulate questions and hypothesis, to identify independent variable, design their experiment and design data table. Basic science processes are vital for science learning and concept formation at the primary and junior secondary school levels. The more difficult and integrated science process skills are more appropriate at the secondary and tertiary school levels for the formation of models, experimenting and inferring (Akinbobola and Afolabi, 2010). However, the biology laboratory manuals in these universities are deficient in the integrated science process skills.

Reading is the most common pre-lab activity but observation and questions were rarely asked. The result is found to be in agreement with those of Germann et al. (1996), Haskins (2000), Basey et al. (2000) and Tweedy and Hoese(2005). Pre - lab reading should lead to enhanced learning outcomes for students as well as better meeting ethical guidelines for instructors to design practical activities. Haskins (2000) conducted a study on determining whether the material found in $\mathrm{ABC}$ promotes scientific inquiry through the inclusion of science process skills and the type and character of laboratory activities in Columbia and found that all laboratory activities provide a pre-laboratory activities and most often skill of learning techniques and manipulating apparatus, and the least was student planning and designing. Similarly, Tweedy and Hoese (2005) conducted Laboratory Task Analysis Instrument of diffusion activities of two-year and four-year colleges in the United States. They found that most manuals did not include much inquiry, often failed to engage students in the planning and designing of the activities. In this study, manual analysis revealed that the laboratory experiments conducted in the universities were confirmatory rather than investigative experiments. Confirmatory experiments are planned by the teacher with the goal in mind of confirming the theoretical material studied in class and the students perform the experiments according to the teacher's instructions, then organize their results, analyze them, and draw conclusions (Katchevich, Hofstein and Mamlok-Naaman, 2013). Like Basey et al. (2000), laboratory manuals were deficient in deriving problems/hypotheses, variables, methods, and extensions. Result from the analysis of the undergraduate biology 
laboratory manuals of this study revealed that a high percentage of basic science process skills in the laboratory as compared to the integrated science process skills. The finding is in agreement with that of the results of Ongowo and Indoshi(2013) in Kenya that a high percentage of basic science process skills as compared to the integrated science process skills in the practical examination questions.

\section{Conclusions}

Biology education plays a significant role in various areas of human development. To achieve this goal, universities need to evaluate the attainment of the intended objectives.

The aim of this study was to evaluate the extent of scientific skill inclusions in the laboratory manuals. The result showed that laboratory manuals possess high percentage rate of basic science process skills as compared to the integrated science process skills. The biology laboratory manuals in these universities do not provide much opportunity for students to be engaged in the integrated science process skills while the integrated (higher order) science process skills are important for reflective thinking, creativity and problem solving than the basic skills. This means that the graduates from these universities may not be in a position to participate effectively in activities requiring problem solving skills which are developed from the acquisition of integrated science process skills. Hence, there is need to increase the number of integrated process skills in the undergraduate biology laboratory manuals.

The methodology and instruments used in this study will have great importance not only in Ethiopia, but also in other countries, and not only in biology undergraduate laboratories, but also in other sciences, such as chemistry and physics to evaluate the acquisition of the higher order science process skills. The findings of this study would also provide the universities with the opportunities to use time- and cost-effective laboratory teaching by evaluating the standards of the laboratory manuals and take intervention that would enable the students to be productive and contribute towards global excellence in their practical skills.

From the results of the analysis, the following recommendations are drawn:

- Educators should review the laboratory manuals that are available and implement changes that would promote the students' use of all scientific skills. 
- Standard harmonized laboratory manuals for each course should be developed

by Ministry of Education which allows students the opportunity to engage in scientific thinking and participate in scientific inquiry.

- Educators should evaluate the laboratory manuals with an inventory such as the one derived in this paper, and attempt to address the seven categories of Laboratory Task Analysis in each lab course.

\section{References}

AAAS (American Association for the Advancement of Science) (1993). Benchmarks for scientific literacy: A Project 2061 report. New York: Oxford University Press.

Abraham, I. and Millar, R. (2008). Does Practical Work Really Work? A Study of the Effectiveness of Practical Work as a Teaching and Learning Method in School Science, International Journal of Science Education, 30(14), 1945-1969.

Akinbobola, A.O. and Afolabi, F.( 2010). Analysis of Science Process Skills in West African Senior Secondary School Certificate Physics Practical Examinations in Nigeria, American-Eurasian Journal of Scientific Research, 5 (4): 234-240.

Banchi, H., and Bell ,R.(2008). The many levels of inquiry. Science and Children, 46 (2), 26-29. Retrieved from http://www.eric.ed.gov/

Basey, J. M., Mendelow, T. N. and Ramos, C. N.(2000). Current trends of community college lab curricula in biology: an analysis of inquiry, technology, and content. Journal of Biological Education, 34 (2), 80 -86.

Domin, D.S (1999). A content analysis of general chemistry laboratory manuals for evidence of higher-order cognitive Tasks. Journal of Chemical Education, 76(1), 109-112.

Gauchet, C. (2011). Effects of a novel science curriculum versus tradition science curriculum on problem solving skills and attitudes for 10th grade students. Doctoral dissertation presented to Trevecca Nazarene University. Retrieved from ProQuest Dissertation and Theses database. (UMI number: 3413101)

Germann, P. J., Haskins, S. and Auls, S. (1996) Analysis of Nine High School Biology Laboratory Manuals: Promoting Scientific Inquiry. Journal of Research in Science Teaching, 33(5), 475499.

Harmonized Curriculum for BSc Degree Program in Biology (2009), Addis Ababa, Ethiopia (unpublished), 3-5

Haskins, S. (2000). An analysis of Laboratory Activities found in Applications in Biology/Chemistry: A contextual approach to Laboratory Science $(A B C)$. A doctoral dissertation presented to The Faculty of the Graduate school, University of Missouri-Colombia. Available from Bell and Howell information and learning database. (UMI number: 9999294)

Hofstein, A., \& Lunetta, V.N. (2003). The laboratory in science education: Foundations for the twenty-first century. Science Education, 88(1), 28-54.

Hofstein, A., and Mamlok-Naaman, R. (2007). The laboratory in science education: the state of the art. Chemistry Education Research and Practice, 8 (2), 105-107.

Hunt, L., Koender, A. and ynnild, V. (2012). Assessing practical laboratory skills in undergraduate molecular biology courses. Assessment \& Evaluation in Higher Education, 37(7), 861-874.

Jack, G.U. (2013). The Influence of Identified Student and School Variables on Students' Science Process Skills Acquisition, Journal of Education and Practice, 4(5), 16-22

Katchevich, D., Holstein, A. and Mamlok-Naaman, R. (2013). Argumentation in the Chemistry Laboratory: Inquiry and Confirmatory Experiments. Research in Science Education, 43, 317345.

Kuddus, R.H. (2013). Who Should Change Biology Education: An Analysis of the Final Report on the Vision and Change in Undergraduate Biology Education Conference. International Journal of Biology Education, 3(1):63-83. 
National Committee on Science Education Standards and Assessment.(1993). National science education standards: An enhancement sampler. Washington, DC: National Research Council.

Ongowo, R.O. and Indoshi, F. C. (2013). Science Process Skills in the Kenya Certificate of Secondary Education Biology Practical Examinations. Creative Education, 4(11), 713-717.

Özgelen, S. (2012). Students' Science Process Skills within a Cognitive Domain Framework. Eurasia Journal of Mathematics, Science \& Technology Education, 8(4), 283-292.

Pešaković, D., Flogie, A. and Aberšek, B. (2014). Development and Evaluation of a CompetenceBased Teaching Process for Science and Technology Education. Journal of Baltic Science Education, 13(5), 740-755.

Peters, C.J. (2006). An Assessment Template for Introductory College Biological Laboratory Manuals. A doctoral dissertation Submitted to Illinois State University in Partial Fulfilment of the Requirements for the Degree of Doctor of Education, Illinois State University. Available from ProQuest Dissertation and Thesis database. (UMI Number: 3233946)

Psillos, D. and Niedderer H. (2002. The Teaching and learning in the science Laboratory, (eds), Kluwer Academic Publishers, (pp 9-20).

Saha, G.S. (2001). Implementing the Science Assessment Standards: Developing and validating a Set of Laboratory Assessment Tasks in High School Biology. A doctoral dissertation submitted to the Faculty of the Graduate School of State University of New York at Buffalo. Available from Bell and Howell information and learning database. (UMI number: 9997996)

Sheeba, M.N. (2013). An Anatomy of Science Process Skills In The Light of the Challenges to Realize Science Instruction Leading to Global Excellence in Education. Educationia Confab, 2(4), 108-113.

Sundberg, M. D. and Moncada,G.J. (1994) Creating effective investigative laboratories for undergraduates. BioScience, 44(10), 698-704. http://doi.org/10.2307/1312513

Tamir, P. and Lunetta, V.N. (1978). An Analysis of Laboratory Inquiries in the BSCS Yellow Version. The American Biology Teacher, 353-357.

Tarrant, T.M. (2005). Construction, Implementation, and evaluation of an undergraduate Biology Laboratory Teaching model. A doctoral dissertation submitted to Michigan State University In partial fulfillment of the requirements for the degree of doctor of philosophy in biology. Available from ProQuest Dissertations and Theses database. (UMI number: 3204806)

Tessier, J. (2010). An Inquiry-Based Biology Laboratory Improves Pre-service Elementary Teachers' Attitudes about Science. Journal of College Science Teaching, 84-90.

Tweedy, M.E. and Hoese, W.J (2005). Diffusion activities in college laboratory manuals. Journal of Biological Education, 39(4), 150-155. 